Al-Azhar Bull. Sci. Vol. 19, No. 2 (Dec.): pp. 83-94, 2008.

\title{
COBALT(II) COMPLEX BINDING WITH COPOLYMER AS A PROFICIENT CATALYST FOR OXIDATION OF CATECHOL
}

\author{
AHMED IMAM HANAFY \\ Chemistry Department, Faculty of Science, Al-Azhar University, Nasr City, Cairo, \\ Egypt \\ ahmedih@yahoo.com
}

\begin{abstract}
The metallopolymer cobalt(II) complex of a simple pyridine- and amide-containing copolymer $\left(\mathrm{Co}^{\left.\mathrm{II}-\mathbf{P}_{9}\right)}\right.$ was prepared and characterized with IR and ${ }^{1} \mathrm{H}$ NMR. The ${ }^{1} \mathrm{H}$ NMR spectrum of the copolymer indicates that the average repeating unit of the copolymer $\mathbf{P}_{\mathbf{9}}$ is vinyl pyridine:acrylamide $=5: 1$. The IR spectra suggest that cobalt is bound to the polymer through the pyridine nitrogen atom and the acrylamide does not participate in the binding. The oxidation of catechol by $\mathrm{Co}^{\mathrm{II}}-\mathbf{P}_{\mathbf{9}}$ in the presence of $7.5 \mathrm{mM} \mathrm{H}_{2} \mathrm{O}_{2}$ exhibits enzyme-like pre-equilibrium kinetics, yielding $k_{\text {cat }}=0.026 \pm 0.3 \mathrm{~s}^{-1}$, dissociation constant $K^{\prime}=1.9 \pm 0.6$ $\mathrm{mM}$, and $k_{\text {cat }} / K^{\prime}=13.7 \mathrm{M}^{-1} \mathrm{~s}^{-1}$. The inert 4,5-dichlorocatechol is also oxidized by $\mathrm{Co}^{\mathrm{II}}-\mathbf{P}_{\mathbf{9}}$ in absence of $\mathrm{H}_{2} \mathrm{O}_{2}$ to afford rate constants of $k_{\text {cat }}=(3.1 \pm 0.2) \times 10^{-4} \mathrm{~s}^{-1}$ and $K^{\prime}=0.7 \pm 0.1$ $\mathrm{mM}$. This study has introduced a simple catalase-like system to explore the mechanism of $\mathrm{Co}(\mathrm{II})$-centered redox chemistry and its application.
\end{abstract}

Key words; Catechol, oxidase, copolymer, vinyl pyridine, inhibition

\section{Introduction}

The oxidation of organic substrates with molecular oxygen under mild conditions is of great interest for industrial and synthetic processes, especially from economical and environmental points of view [1]. Although the reaction of organic compounds with dioxygen is thermodynamically favored it is kinetically hindered due to the triplet ground state of $\mathrm{O}_{2}$. The synthesis and investigation of functional model complexes for metalloenzymes with oxidase or oxygenase activity is therefore of great interest for the development of new and efficient catalysts for oxidation reactions.

Catechol oxidase, tyrosinase, and polyphenol oxidases are analogous metalloenzymes which oxidize phenolic compounds to the corresponding quinones in the presence of oxygen. Catechol oxidase exclusively catalyzes the oxidation of catechols to quinones without acting on tyrosine [2]. This reaction is of great importance in medical diagnosis for the determination of the hormonally active 
catecholamines adrenaline, noradrenaline and dopa [3]. There have been great efforts to synthesize model complexes as functional or structural models for catechol oxidases or related copper containing enzymes [4-9].

Transition metal complexes have been widely studied in the area of bioinorganic, bio-organic, and catalytic chemistry [10-13]. Cobalt complexes are interesting compounds in the field of catalysis not only because they are relatively inexpensive, but also because of the rich spectroscopy of the cobalt(II) center [14]. Cobalt-based catalysts are important and widely used materials in the industrial process, including hydrogenation, hydrotreating, and combustion processes [15].

In the field of biomimetic dioxygen carriers, the ability of Schiff base-cobalt complexes to bind dioxygen reversibly has been extensively examined since the late 30's, when Tsumaki discovered that the Co(Salen) complex could carry dioxygen reversibly [16]. Over the past few decades many Schiff base-cobalt complexes were synthesized and their thermodynamic and kinetic oxygenation properties characterized [17-21]. Recently, we have prepared and investigated a copolymer $\left(\mathbf{P}_{1}\right)$ of 4-vinyl pyridine $(4 \mathrm{Vp})$ and acrylamide $(\mathrm{Ac})$ with an average repeating unit (RU) of $4 \mathrm{Vp}_{3} \mathrm{Ac}_{1}$ which has been demonstrated to bind metal ions with a stoichiometry of metal:RU $=1: 1$ [22]. The copper complex of $\mathbf{P}_{\mathbf{1}}\left(\mathrm{Cu}^{\mathrm{II}}-\mathbf{P}_{\mathbf{1}}\right)$ has been demonstrated to show significant hydrolytic [22] and oxidative activities [23]. Hence we have demonstrated that metal-binding polymers are a versatile and tunable framework for the design of novel catalysts. Herein, the preparation of a copolymer analogous to $\mathbf{P}_{\mathbf{1}}$ and the oxidative activity of its cobalt (II) complex are described. The significant catechol oxidation activity of this complex suggests that this complex can serve as a model for catechol oxidase. The primary intention is to elucidate trends in reactivity that might be valuable for the use of this class of metallopolymer complexes in oxidation catalysis.

\section{Experimental Section}

The reagents 4-vinylpyridine was obtained from Across Organics (Fair Lawn, NJ). Acrylamide was from BioRad (Richmond, CA); HEPES, chelex resin, 3methyl,2-benzothiazolinone hydrazone (MBTH), catechol (Cat) and 4,5 dichlorocatechol (DCC) were from Sigma-Aldrich (St Louis, MO). The buffer solutions were treated with Chelex resin to remove any trace amount of metal ions.

Polymer synthesis: Copolymers of 4-vinylpyridine $(4 \mathrm{Vp})$ and acrylamide (Ac) were prepared according to published procedures [24] by mixing freshly distilled 4vinylpyridine and recrystalized acrylamide in DMF, then followed by 
polymerization with the initiator 2,2'-azoisobutyronitrile (AIBN). The copolymers were precipitated in ethyl acetate, then filtered and dried in a vacuum oven at $40^{\circ} \mathrm{C}$. The formation of the polymer was verified with a Bruker ADX 250 NMR spectrometer. A total recycle time of $\sim 10 \mathrm{~s}$ was used to ensure complete relaxation of the ${ }^{1} \mathrm{H}$ NMR signals. Infrared absorption spectra in the range $\left(600-4000 \mathrm{~cm}^{-1}\right)$ were measured on a Nicolet Avatar 320 FTIR spectrophotometer at University of South Florida, USA. CsI was usually used with dried Nujol as mulling agent for the solid compounds. Occasionally, spectra were recorded using potassium bromide discs. Calibration of the frequency reading was made with a polystyrene film.

Reactivity studies: The initial rates of the oxidation of different concentrations of catechol and 4,5 dichlorocatechol ranging from 0.2 to $5.0 \mathrm{mM}$ by $20 \mu \mathrm{M} \mathrm{Co}^{\mathrm{II}}-\mathbf{P}_{\mathbf{9}}$ (in terms of metal concentration) in buffered aqueous solution (50\% water/methanol) at $\mathrm{pH} 8.0$ in the presence of $\mathrm{H}_{2} \mathrm{O}_{2}$ were determined on a Varian Cary 50 spectrophotometer. The oxidation of the catechol and 4,5-dichlorocatechol can be monitored at $500 \mathrm{~nm}$ by the use of 3-methyl,2-benzothiazolinone hydrazone (MBTH) as an ortho-quinone indicator [25].

\section{Results and discussion}

Vinyl pyridine and acrylamide were chosen for the preparation of metallopolymers based on the ability to bind transition metals (pyridine moiety) and form $\mathrm{H}$-bonding through the amide group, thus may loosely mimic the active site environment of various oxidoreductase enzymes.

An average of three integrations of ${ }^{1} \mathrm{H}-\mathrm{NMR}$ spectra of the copolymer $\boldsymbol{P}_{\boldsymbol{g}}$ was used for the calculation of the copolymer composition. The monomer composition of the copolymer can be calculated from the ratio of these integrals, which are proportional to the number of the protons that contribute to the peaks. Figure 1 shows the ${ }^{1} \mathrm{H}-\mathrm{NMR}$ spectrum of the copolymer dissolved in $\mathrm{d}_{6}$ DMSO. Peaks at 8.2 , and $6.6 \mathrm{ppm}$ are supposed to be due to two pyridine protons in the $o$-position and two pyridine protons in $m$-position. These two peaks are also supposed to be equally integrated.

The difference in the integration of these two peaks (0.19) is due to overlapping of $\mathrm{NH}_{2}$ with the two pyridine protons (Fig. 1A). This assumption is proposed, based on the following evidences; the difference in the integration between the two peaks disappears upon deuteration (Fig. 1B), supporting the idea that this (0.19) is attributed to $\mathrm{NH}_{2}$ amide. This data is also confirmed by subtracting the deuterated spectrum from the original one showing two peaks due to this difference (Fig.1C), 
which is attributable to $\mathrm{NH}_{2}$. The ${ }^{1} \mathrm{H}-\mathrm{NMR}$ spectral data suggest that the monomer ratio of the copolymer is $5: 1$ of $4 \mathrm{Vp}$ : Ac i.e. the copolymer repeating unit (RU) contains $4 \mathrm{Vp}_{5} \mathrm{Ac}_{1}$. The molecular weight of this copolymer is found to be more than 50 kilo Dalton, based on membrane cut off experiment.

Metal binding and catalyst stoichiometry: The pyridine- and acrylamidecontaining copolymer family has been previously determined to bind various metal ions; however, detailed investigation of the coordination chemistry and catalytic properties was lacking [26] until a recent investigation on $\mathrm{Cu}^{\mathrm{II}}$ binding and hydrolytic activity of a copolymer of $\mathrm{RU}=4 \mathrm{Vp}_{3} \mathrm{Ac}_{1}$ [22]. The IR spectrum of the copolymer $\mathbf{P}_{9}$ exhibits two bands at 3378 and $3180 \mathrm{~cm}^{-1}$ which are attributed to overlapping water molecules with $\mathrm{N}-\mathrm{H}$ (asymmetric and symmetric) of $\mathrm{NH}_{2}$. The band at $1600 \mathrm{~cm}^{-1}$ is assigned to $\beta \mathrm{NH}_{2}$ [27]. $v_{(\mathrm{C}=0)}$ stretching band is observed at $1670 \mathrm{~cm}^{-1}$, while the $v_{(\mathrm{C}-\mathrm{H})}$ signal aliphatic band appears at $2931 \mathrm{~cm}^{-1}$ [28]. The two bands at 1487 and $1450 \mathrm{~cm}^{-1}$ are attributed to $v_{(\mathrm{C}=\mathrm{N})}$ [29]. The lower intensity of carbonyl band at $1671 \mathrm{~cm}^{-1}$ and $\beta \mathrm{NH}_{2}$ at $1598 \mathrm{~cm}^{-1}$ as well as the appearance of $\mathrm{NH}_{2}$ at lower wavenumbers 3334 and $3168 \mathrm{~cm}^{-1}$ in the IR spectrum of $\mathbf{P}_{\mathbf{9}}$ in Nujol indicating that the $\mathrm{NH}_{2}$ amide and carbonyl are taking part in hydrogen bonding [3032].

On comparing the IR spectrum of the $\mathrm{Co}(\mathrm{II})$ complex $\left(\mathrm{Co}^{\mathrm{II}}-\mathbf{P}_{\mathbf{9}}\right)$ to that of the copolymer, that data show that the copolymer binds to $\mathrm{Co}$ (II) through nitrogen atom of vinyl pyridine and the carbonyl group doesn't participate in the binding. This assumption was confirmed by disappearing one of the $v_{(\mathrm{C}=\mathrm{N})}$ bands and shifting the other one to higher wavenumber. The bands at 1670 and $1600 \mathrm{~cm}^{-1}$ due to $v_{(\mathrm{C}=0)}$ and $\beta \mathrm{NH}_{2}$, respectively, remain at the same positions. The position of bands at 3184 and $2928 \mathrm{~cm}^{-1}$ attributable to $\mathrm{N}-\mathrm{H}$ symmetric stretching of $\mathrm{NH}_{2}$ and aliphatic $\mathrm{v}_{(\mathrm{C}-\mathrm{H})}$ [29] remain unchanged. The electronic spectrum of the solid deep blue $\mathrm{Co}^{\mathrm{II}}$-P9 dissolved in DMSO on heating displays three bands at 610, $630(\mathrm{sh})$ and $665 \mathrm{~nm}$ in the visible region. The band at $665 \mathrm{~nm}$ is attributed to ${ }^{4} \mathrm{~A}_{2} \rightarrow{ }^{4} \mathrm{~T}_{1}(\mathrm{P})$ transition and clearly indicates that the geometry around $\mathrm{Co}(\mathrm{II})$ is tetrahedral geometry [33]. All these data together with the cobalt content of $\mathrm{Co}^{\mathrm{II}}-\mathbf{P}_{\mathbf{9}}(9.1 \mathrm{wt}$. \%) suggest the binding of cobalt (II) to at most four vinyl pyridine nitrogen atoms.

In order to determine the metal-to-polymer stoichiometry for catalysis, $40 \mu \mathrm{M}$ RU of the polymer in an aqueous methanol solution $(50 \%$ methanol in $50 \mathrm{mM}$ HEPES buffer at $\mathrm{pH} 8.0$ ) was titrated with an aqueous solution of $\mathrm{Co}^{\mathrm{II}}$ and the catalytic activity of the metal complex toward the oxidation of $1.0 \mathrm{mM}$ catechol in 
presence of $10 \mathrm{mM} \mathrm{H}_{2} \mathrm{O}_{2}$ (the reactivity studies are discussed below) has been checked at $\mathrm{pH} 8.0$ and $25{ }^{\circ} \mathrm{C}$. A gradual increase in activity with $\mathrm{Co}^{\mathrm{II}}$ addition was observed until two equivalents of $\mathrm{Co}^{\mathrm{II}}$ was added with respect to [RU] to reach a plateau, indicating a 2:1 stoichiometry for metal binding to each RU necessary for catalysis. This activity profile can be best fitted to the Hill equation (Eq. 1) [34] with a Hill coefficient of $\theta=1.93$ and $r^{2}=0.99$ (Fig. 2, solid trace), but not to a quadratic equation for $2: 1$ binding mode $\left(r^{2}=0.97\right.$; Fig. 2 , dashed trace). The affinity constant for the binding of $\mathrm{Co}^{\mathrm{II}}$ to the copolymer is calculated to be $(1.79 \pm 0.7) \times$ $10^{5} \mathrm{M}^{-1}$. This observation reveals an interesting metal binding property of the polymer wherein cooperativity in activity is induced upon metal binding. Cooperativity is a unique property of a number of proteins and enzymes, such as hemoglobin, which is not usually observed in simple chemical systems. This observation suggests that metallopolymers may serve as good functional models for metalloproteins and metalloenzymes, despite the heterogeneous nature of copolymers in their composition and structure.

Oxidation of catechol: Oxidation of catechol to produce quinone is a twoelectron process. The reaction can be followed by monitoring the absorbance of the red adduct formed by $o$-quinone with $\mathrm{MBTH}$ at $500 \mathrm{~nm}\left(\varepsilon=3.25 \times 10^{4} \mathrm{M}^{-1} \mathrm{~cm}^{-1}\right)$ [25]. To ensure that the activity is due to the metallopoymer, the copolymer and cobalt(II) ion have been used as controls in the oxidation of the catechol. The copolymer $\left(\mathbf{P}_{\mathbf{9}}\right)$ showed a negligible activity toward the oxidation of catechol, while the cobalt (II) ion showed activity five times lower than that of the metallopolymer. In order to gain further information about the mechanism of the oxidative activity of the $\mathrm{Co}^{\mathrm{II}}-\mathbf{P}_{\mathbf{9}}$ and its interaction with $\mathrm{H}_{2} \mathrm{O}_{2}$, catechol has been used as a substrate to provide detailed kinetic information. The oxidation rates of catechol by $20 \mu \mathrm{M}$ $\mathrm{Co}^{\mathrm{II}}-\mathbf{P}_{\mathbf{9}}$ in term of $\left[\mathrm{Co}^{\mathrm{II}}\right]$ at different concentrations of catechol have been determined in the presence of different amounts of $\mathrm{H}_{2} \mathrm{O}_{2}$. The rate of catechol oxidation is found to be nonlinear, reaching a plateau at high catechol concentrations which suggest an enzyme-like pre-equilibrium kinetics. This kinetics can be described as the binding of catechol with the catalyst $\mathrm{Co}^{\mathrm{II}}-\mathbf{P}_{\mathbf{9}}$ to form a transient substrate-catalyst complex, followed by the conversion of the bound substrate into products (Eq. 2). The rate law for this reaction can be obtained with steady-state approximation similar to the Michaelis-Menten kinetics in enzyme catalysis. The rate law for this reaction mechanism can be expressed as in (Eq. 3), wherein $\mathrm{K}^{\prime}=\left(k_{-1}+k_{\text {cat }}\right) / k_{1}$ is the dissociation constant of the $\left(\mathrm{Co}^{\mathrm{II}}-\mathbf{P}_{\mathbf{9}}\right)-\mathrm{S}$ complex similar to the Michaelis constant in enzyme kinetics. The reaction in the presence of saturation amount of $\mathrm{H}_{2} \mathrm{O}_{2}(7.5 \mathrm{mM})$ produces a first-order rate constant $k_{\text {cat }}=0.026 \pm 0.03 \mathrm{~s}^{-1}\left(\mathrm{t}_{1 / 2}=26.6\right.$ 
s), The apparent dissociation constant $\mathrm{K}^{\prime}=1.9 \pm 0.6 \mathrm{mM}$ and a significant catalytic efficiency $k_{\text {cat }} / \mathrm{K}^{\prime}=13.7 \mathrm{M}^{-1} \mathrm{~s}^{-1}$ as the second order rate constant (Fig. 3), While $k_{\text {cat }}$ value of $4.62 \times 10^{-3} \mathrm{~s}^{-1}$ is obtained in the absence of $\mathrm{H}_{2} \mathrm{O}_{2}$. The catalysis shows 5.5 $\times 10^{4}$ times rate increase in terms of the first-order rate constant $\left(k_{\mathrm{cat}} / k_{\mathrm{o}}\right.$, wherein $k_{\mathrm{o}}=$ $4.74 \times 10^{-7} \mathrm{~s}^{-1}$ is the rate constant for the uncatalyzed reaction) this catalyst shows only 5.5 times lower than what has been reported with $\mathrm{Cu}^{\mathrm{II}} \beta$-amyloid [35].

The oxidation of catechol as a function of $\mathrm{H}_{2} \mathrm{O}_{2}$ also shows a saturation pattern at high concentrations, indicating direct binding of this oxidant to the active metal center. Therefore, both catechol and $\mathrm{H}_{2} \mathrm{O}_{2}$ are considered to be substrates. For a bisubstrate binding mechanism, the binding of two substrates (catechol and $\mathrm{H}_{2} \mathrm{O}_{2}$ ) to the active center of $\mathrm{Co}^{\mathrm{II}}-\mathbf{P}_{\mathbf{9}}$ can be described in terms of the Hanes equation (Eq. 4) [36]. Hanes analysis was used to calculate the apparent and intrinsic dissociation constants (Fig. 4). It is important to determine the rates at varying amounts of $\mathrm{H}_{2} \mathrm{O}_{2}$ with a fixed concentration of catechol and vice versa. Figures $5 \mathrm{~A}$ and $5 \mathrm{~B}$ show the conversion of the plot in Figure 4 to a secondary plot of the slope $\left(1 / \mathrm{V}_{\max }\right)$ and $\mathrm{y}$-intercept $\left(\mathrm{K}_{\text {app }} / \mathrm{V}_{\max }\right)$ as a function of $1 /\left[\mathrm{H}_{2} \mathrm{O}_{2}\right]$, affording $\mathrm{K}_{\text {(cat) }}^{\prime}=2.73 \mathrm{mM}, \mathrm{K}_{\mathrm{i} \text { (cat) }}$ $=2.58 \mathrm{mM}, \mathrm{K}^{\prime}{ }_{(\mathrm{H} 2 \mathrm{O} 2)}=4.30 \mathrm{mM}$, and $\mathrm{K}_{\mathrm{i}(\mathrm{H} 2 \mathrm{O} 2)}=3.23 \mathrm{mM}$. The $\mathrm{K}^{\prime} / \mathrm{K}_{\mathrm{i}}$ ratio is 1.06 for catechol and 1.33 for $\mathrm{H}_{2} \mathrm{O}_{2}$ which indicate the bindings of these two substrates are not mutually exclusive and the presence of only a small cooperativity between the two substrates [37].

To investigate the efficiency of the catalyst $\mathrm{Co}^{\mathrm{II}}-\mathbf{P}_{\mathbf{9}}$ on the oxidation of less activated catechols, 4,5-dichlorochatechol (DCC) has been used as a substrate. The rate of oxidation of various amounts of DCC by $20 \mu \mathrm{M} \mathrm{Co}^{\mathrm{II}}-\mathbf{P}_{\mathbf{9}}$ in terms of $\left[\mathrm{Co}^{\mathrm{II}}\right]$ in the absence of $\mathrm{H}_{2} \mathrm{O}_{2}$ reaches a plateau (Fig. 6) indicating pre-equilibrium mechanism, which yields a quite significant first-order rate constant $k_{\text {cat }}=(3.1 \pm 0.2)$ $\times 10^{-4} \mathrm{~s}^{-1}$ and $\mathrm{K}^{\prime}=0.70 \pm 0.09 \mathrm{mM}$. The oxidation of DCC in the presence of 7.5 $\mathrm{mM} \mathrm{H}_{2} \mathrm{O}_{2}$ affords $\mathrm{k}_{\text {cat }}=(1.03 \pm 0.03) \times 10^{-2} \mathrm{~s}^{-1}$ and $\mathrm{K}^{\prime}=2.1 \pm 0.8 \mathrm{mM}$.

\section{Conclusion}

The cobalt(II) complex of a simple pyridine-and amide-containing copolymer $\left(\mathbf{P}_{\mathbf{9}}\right)$ was prepared and characterized by means of IR and ${ }^{1} \mathrm{H}-\mathrm{NMR}$. The $\mathrm{Co}^{\mathrm{II}}-\mathbf{P}_{\mathbf{9}}$ complex shows a significant oxidation activity towards catechol oxidation. The oxidation of catechol by $\mathrm{Co}^{\mathrm{II}}-\mathbf{P}_{\mathbf{9}}$ in the presence of $\mathrm{H}_{2} \mathrm{O}_{2}$ exhibits enzyme-like kinetics, yielding a significant first-order rate constant $k_{\text {cat }}=0.026 \pm 0.30 \mathrm{~s}^{-1}$, dissociation constant $\mathrm{K}^{\prime}=1.9 \pm 0.6 \mathrm{mM}$ and $k_{\text {cat }} / \mathrm{K}^{\prime}=13.7 \mathrm{M}^{-1} \mathrm{~s}^{-1}$. The much less activated catechol compound 4,5-dichlorocatechol can also be oxidized by $\mathrm{Co}^{\mathrm{II}}-\mathbf{P}_{\mathbf{9}}$ in absence and presence of $\mathrm{H}_{2} \mathrm{O}_{2}$ to afford rate constants $\mathrm{k}_{\mathrm{cat}}=3.1 \times 10^{-4}$ 
and $1.03 \times 10^{-2} \mathrm{~s}^{-1}$ respectively. The study presented herein has introduced a simple functional model system of catechol oxidase-like enzyme to explore more information about the mechanism of the oxidation chemistry of catechol and analogues.

$$
\begin{aligned}
& \frac{\mathrm{V}_{\mathrm{o}}}{\mathrm{V}_{\max }}=\frac{\left[\mathrm{Co}-\mathrm{P}_{9}\right]^{\theta}}{\mathrm{K}_{\mathrm{x}}+\left[\mathrm{Co}-\mathrm{P}_{9}\right]^{\theta}} \\
& \text { Eq. } 1
\end{aligned}
$$

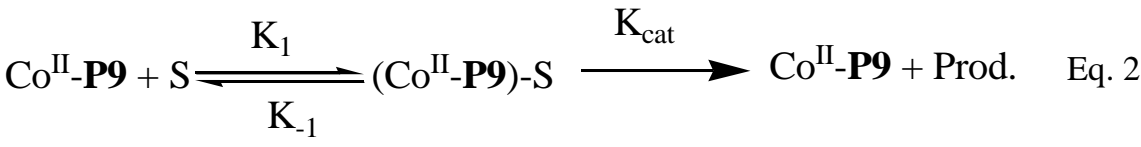

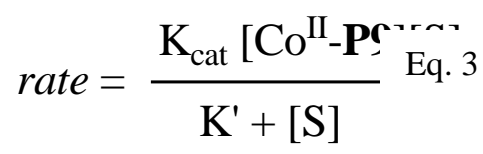

$\frac{[\mathrm{Cat}]}{\mathrm{V}_{\mathrm{o}}}=\frac{\left(1+\left(\mathrm{K}_{\left(\mathrm{H}_{2} \mathrm{O}_{2}\right)}^{\prime} /\left[\mathrm{H}_{2} \mathrm{O}_{2}\right]\right.\right.}{\mathrm{V}_{\max }}[\mathrm{Cat}]+\frac{\mathrm{K}_{\mathrm{cat}}^{\prime}}{\mathrm{V}_{\max }}\left(1+\frac{\mathrm{K}_{\mathrm{i}\left(\mathrm{H}_{2} \mathrm{O}_{2}\right)}}{\left[\mathrm{H}_{2} \mathrm{O}_{2}\right]} \quad\right.$ Eq. 4
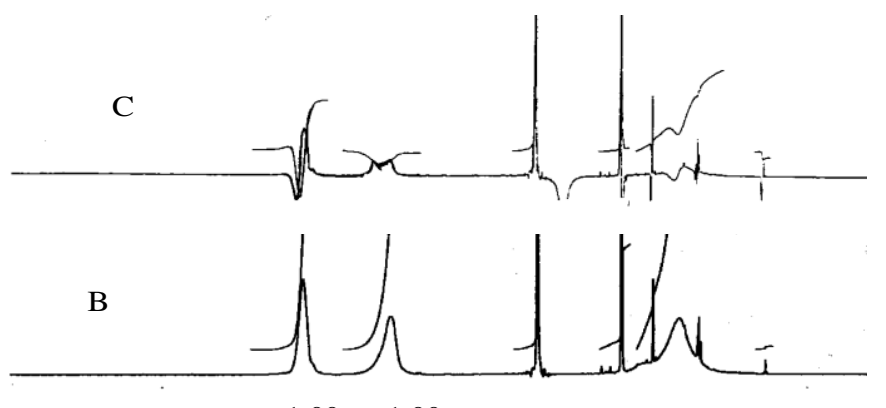

$1.00 \quad 1.00$
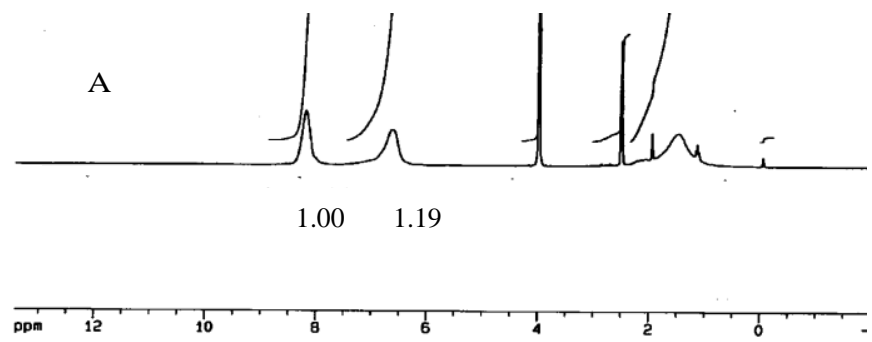

Fig. 1 (A); The ${ }^{1} \mathrm{H}$-NMR signals of the pyridine ring and the amide $\mathrm{NH}_{2}$ protons of the copolymer in DMSO. (B)The copolymer dissolved in DMSO in addition to a few drops of $\mathrm{D}_{2} \mathrm{O}$, where the $\mathrm{NH}_{2}$ signals are disappeared. (C) The change can be clearly seen in the difference spectrum which reveals the $\mathrm{NH}_{2}$ signals. 


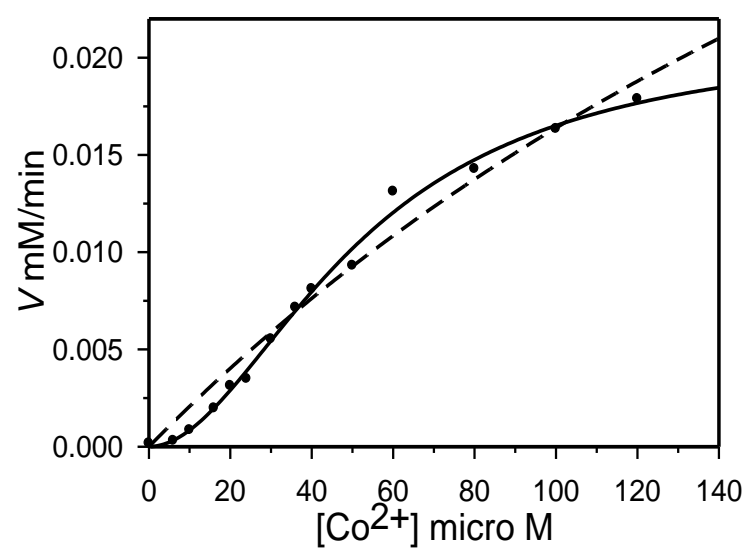

Fig. 2; Co(II) titration to $40 \mu M P_{9}$ and monitored with the initial rate of the oxidation of $1.0 \mathrm{mM}$ catechol in 50\% $\mathrm{MeOH} / \mathrm{buffer}$ solution (HEPES at $\mathrm{pH} \mathrm{8.0}$ ) at 25 ${ }^{\circ} \mathrm{C}$. The solid trace is the best fitting to the Hill equation and dashed trace is the best fit to a quadratic equation.

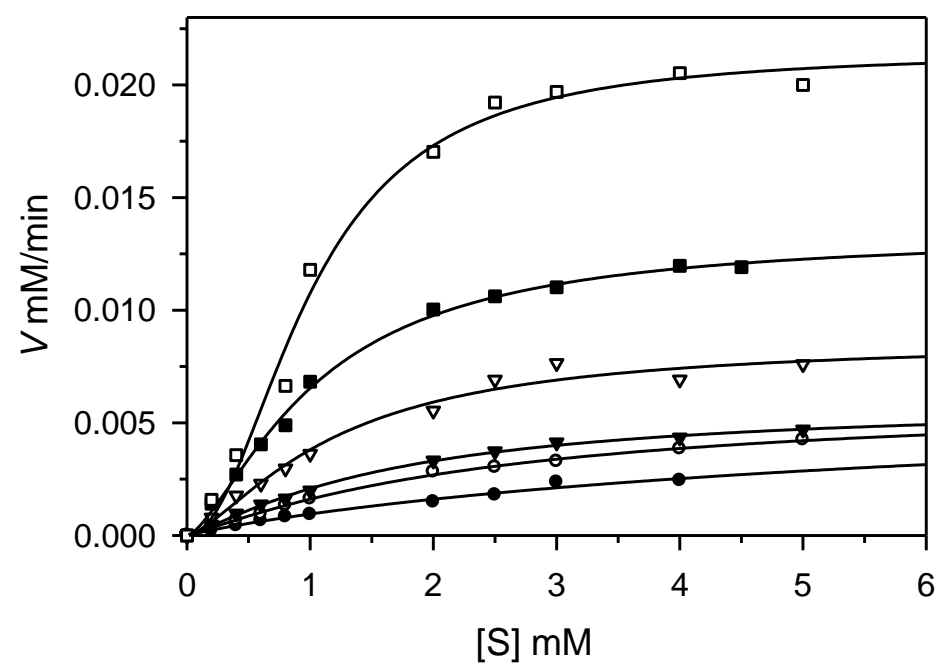

Fig: 3; Initial rate of catechol oxidation by $20 \mu \mathrm{M} \mathrm{Co}^{-P_{9}}$ in $50 \%$ methanol/HEPES buffer solution at pH 8.0 and $25{ }^{\circ} \mathrm{C}$ in the presence of zero $(\bullet), 0.5(\circ), 1.0(\nabla)$, 2.5( $\nabla)$, $5.0(\square)$, and $7.5(\square) \mathrm{mM}_{2} \mathrm{O}_{2}$. The data were fitted to the preequilibrium rate law. There seems to have slight cooperativity in the presence of a high concentration of $\mathrm{H}_{2} \mathrm{O}_{2}$, which can be fitted to the Hill equation as well. 


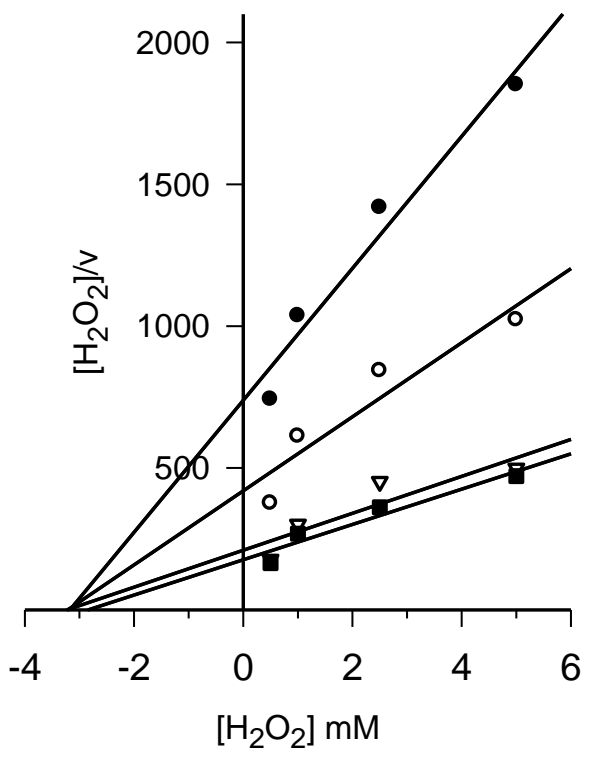

Fig. 4; Hanes plots of the data from Fig. 2 in 50\% methanol/ HEPES buffer solution at pH 8.0 and $25^{\circ} \mathrm{C}$ using $20 \mu \mathrm{M}$ of $\mathrm{Co}^{\mathrm{II}}$-P9.
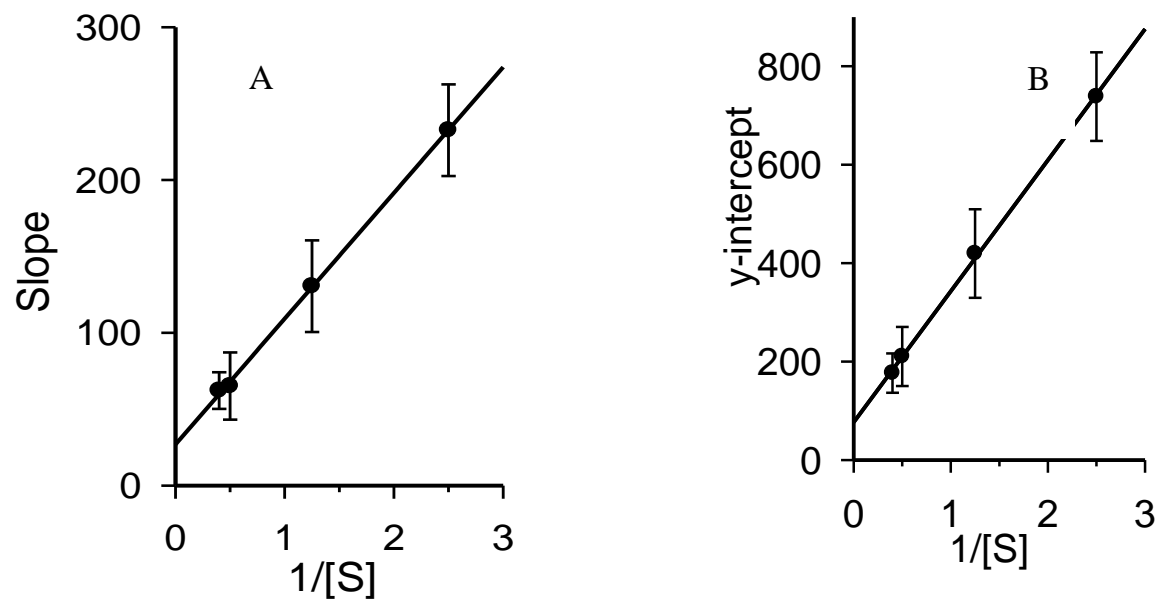

Fig. 5 (A) Replotting the slope obtained from Fig 4 versus $1 /\left[\mathrm{H}_{2} \mathrm{O}_{2}\right]$ reveals true dissociation constants for catechol and $\mathrm{H}_{2} \mathrm{O}_{2}$ in a bi-substrate reaction. (B) Repotting the $y$-intercept obtained from Fig 4 versus $1 /\left[\mathrm{H}_{2} \mathrm{O}_{2}\right]$ reveals true dissociation constants for catechol and $\mathrm{H}_{2} \mathrm{O}_{2}$ in a bi-substrate reaction. 


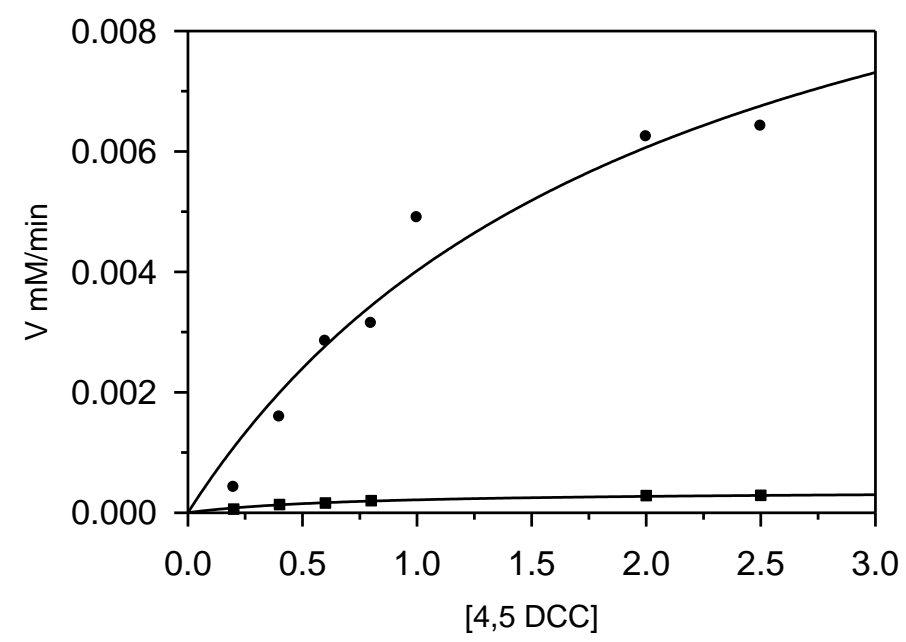

Fig. 6; initial rate of oxidation of 4,5 dichlorocatechol using $20 \mu \mathrm{M} \mathrm{Co-P9}$ without $\mathrm{H}_{2} \mathrm{O}_{2}$ $(\bullet)$, and with $7.5 \mathrm{mM} \mathrm{H}_{2} \mathrm{O}_{2}(\bullet)$. All data were fitted to the pre-equilibrium rate law.

\section{Reference}

1. (a) J. HAGGIN, Chem. Eng. News 71 (1993) 23.

(b) L.I. SIMA NDI, Catalytic Activation of Dioxygen by Metal Complexes, Kluwer, Dordrecht, 1992.

2. M. TRE'MOLIE`RES, J.B. BIETH, Photochemistry, 23 (1984) 501.

3. D. MEIWES, B. ROSS, M. KIESSHAUER, K. CAMMANN, H. WITZEL, M. KNOLL, M. BORCHARDT, C. Sandermaier, Lab. Med. 15 (1992) 24.

4. F. ZIPPEL, F. AHLERS, R. WERNER, W. HAASE, H.-F. NOLTING, B. KREBS, Inorg. Chem., 35 (1996) 3409.

5. J. REIM, R. WERNER, W. HAASE, B. KREBS, Chem. Eur. J. 4 (1998) 289.

6. J. REIM, B. KREBS, J. Chem. Soc., Dalton Trans. (1997) 3793.

7. M. R. MALACHOWSKI, M.G. DAVIDSON, Inorg. Chim. Acta 162 (1989) 199.

8. K. D. KARLIN, Y. GULTNEH, T. NICHOLSON, J. Zubieta, Inorg. Chem. 24 (1985) 3727. 
9. M. R. MALACHOWSKI, M. G. DAVIDSON, J. N. HOFFMAN, Inorg. Chim. Acta 157 (1989) 91.

10. E. V. RYBAK-AKIMOVA, D. H. BUSCH, P. K. KAHOL, N. PINTO, N. W. ALCOCK, H. J. Clase, Inorg. Chem. 36 (1997) 510-520.

11. J. F. LARROW, E. N. JACOBSEN, Y. GAO, Y. P. Hong, X. Y. Nie, C. M. Zepp, J. Org. Chem. 59 (1994) 1939-1942.

12. T. PUNNIYAMURTH, S. VELUSAMY, J. Igbal, Chem. Rev. 105 (2005) 2329-2364.

13. H. OKAWA, H. SAKIYAMA, Pure Appl. Chem. 67 (1995) 273.

14. R. BECHARA, D. BALLOY, J.Y. DAUPHIN, J. Grimblot, Chem. Mater. 11 1999) 1703.

15. L. JI, J. LIN, H. C. ZENG, J. Phys. Chem. B 104 (2000) 1783.

16. T. TSUMAKI, Bull. Chem. Soc. Jpn. 13 (1938) 252-260.

17. D. H. BUSCH, N. W. ALCOCK, Chem. Rev. 94 (1994) 585-623.

18. R. D. JONES, D. A. SUMMERVILLE, F. BASOLO, Chem. Rev. 79 (1979) 139-179.

19. D. CHEN, A. E. Martell, Inorg. Chem. 26 (1987) 1026-1030.

20. D. CHEN, A. E. MARTELL, Y. SUN, Inorg. Chem. 28 (1989) 2647-2652.

21. B. SUN, J. R. CHEN, J. Y. HU, X. J. LI, Chin. Chem. Lett. 12 (2001) 1043-1046.

22. A. I. HANAFY, V. LYKOURINOU, K. S. BISHT, L. J. Ming, Inorg. Chim. Acta 358 (2005) 1247-1252.

23. V. LYKOURINOU, A. I. HANAFY, G. F. Z. DA SILVA, K. S. BISHT, R. W. LARSEN, B. T. LIVINGSTON, A. ANGERHOFER, L. J. MING, Eur. J. Inorg. Chem. (2008), 2584-2592.

24. K. E. GECKLER, N. ARSALANI, J. MACROMOL. Sci., Pure Appli. Chem. A33 (1996) $1165-1179$.

25. (a) G. F. Z. da SILVA, W. M. TAY, L. J. MING, J. Bilo. Chem, 280 (2005) 16601-16609. (b) J. C. ESPIN, J. TUDELA, F. Garcia-Canovas, Anal. Biochem., 259 (1998) 118

26. K. E. GECKLER, N. ARSALANI, J. MACROMOL. Sci., Pure Appli. Chem. A33 (1996) 1165-1179.

27. L. J. BELLAMY, The Infrared spectra of Complex Molecules, John Wiley, London, (1966).

28. R. M. SILVERSTEIN, F. X. WEBSTER, Spectrometric Identifiation of Organic Compounds, John Wiley \& Sons, Inc., New York, (1996). 
29. W. KEMP, Organic Spectroscopy, The Macmillan Press, London and Basingstoke, (1975).

30. R. BLINCK, D. HADZI, J. Chem. Soc., (1959), 453.

31. K. BURGER, I. RUFF, J. Inorg. Nucl. Chem. 27 (1965) 197.

32. J. I. BULLOCK , H. N. TAJIMIR-RIAHI, J. Chem. Soc. Dalton. Trans. (1978) 34.

33. A.B.P. Lever, Inorganic Electronic Spectroscopy, second ed., Elsevier, Amsterdam, 1984, pp. 496-500.

34. S. G. SRIVATSAN, P. NIGAMB , M. S. RAOB , S. Verma, Appl. Catal. A 209 (2001) $327-334$.

35. G. F. Z. Da Silva and L. J. Ming, Angew. Chem. Int. Ed. 2005, 44, 5501 -5504

36. Leskovac, Comperhensive Enzyme Kinetics, Kluwer/Plenum, Boston, (2002), p. 119.

37. J. R. FLORINI, C. S. Vestling, Biochem. Biophys. Acta. 25 (1957) 575-578. 